\title{
Determination of daily eco-hydrographs by the fish spawning habitat suitability model and application to reservoir eco- operation
}

\author{
Ruonan $\mathrm{Li}^{1}{ }^{1}$ Qiuwen Chen, ${ }^{2 *}$ Rui $\mathrm{Han}^{1}{ }^{1}$ and Desuo $\mathrm{Cai}^{3}$ \\ ${ }^{1}$ Research Center for Eco-Environmental Sciences, Chinese Academy of Sciences, Beijing 100085, China \\ ${ }^{2}$ Center for Eco-Environmental Research, Nanjing Hydraulic Research Institute, Nanjing 210029, China \\ ${ }^{3}$ Guangxi Water Authority, Nanning 530023, China
}

\begin{abstract}
Global conflict over water has become increasingly problematic. To meet water demands for economic growth in China, a large number of hydro-projects have been developed and operated, which have significantly altered the natural hydrological regime of many rivers and imposed profound impact on aquatic ecosystems. Conservation of appropriate ecological flow is essential to balance river ecosystem health and economic development. We proposed an innovative method for river eco-hydrograph determination based on the protection of fish spawning habitat. An integrated hydro-environmental-habitat model was developed and applied in de-watered channels in the middle of Yalong River, China, where water was diverted for hydropower generation. Schizothorax chongi (S. chongi), the dominant and commercial indigenous fish, was selected as the target species. Different from previous research, the impacts of fragmentation and water level variation on fish habitat were analysed in the spawning period. Eco-hydrographs for different preservation levels of $S$. chongi spawning habitat were estimated using the developed model, and the suitable one was recommended. Compared with traditional hydrologic and hydraulic methods, the improved habitat method not only determined the ecological water demand of the species more meaningfully but also increased water use efficiency. Copyright (C) 2015 John Wiley \& Sons, Ltd.
\end{abstract}

KEY WORDS ecological hydrograph; fish habitat quality; landscape ecology index; Yalong River; reservoir operation

Received 16 February 2015; Revised 31 August 2015; Accepted 9 October 2015

\section{INTRODUCTION}

Unprecedented growth in water demand is a threat to all major development goals (United Nations Educational, Scientific and Cultural Organization, 2012). Rising energy and food demands, rapid urbanization and climate change have significantly increased pressure on global water supplies (Hanjra and Qureshi, 2010; Hess et al., 2015), particularly in China (Jiang, 2009; Zhao et al., 2013). Since the beginning of the $20^{\text {th }}$ century, over 20000 dams have been built in Chinese rivers for flood management, water resource supply and hydropower production ( $\mathrm{Jia}$ et al., 2010). Their alterations in river flow lead to possible conflicts of interest between river ecosystem conservation and human water demand (Tharme, 2003; Liu et al., 2011). River ecological flow has received increasing attention, as accurate determination of appropriate ecological flow not only benefiting aquatic ecosystems in regulated rivers but also improving the efficiency of

*Correspondence to: Qiuwen Chen, Center for Eco-Environmental Research, Nanjing Hydraulic Research Institute, Nanjing 210029, China. E-mail: qwchen@nhri.cn resource utilization (Akter et al., 2014; Matthews et al., 2014; Jackson et al., 2015).

Concerted development of methodologies for prescribing ecological flow requirements began in the 1940s in the United States Fish and Wildlife Service (Tharme, 2003). After decades of development, more than 200 ecological flow estimation methods have been proposed (Liu et al., 2011), including hydrologic, hydraulic, habitat-based and holistic approaches (Jowett, 1997; Tharme, 2003; Liu et al., 2011). Hydrological approaches are mainly based on historical flow, without consideration of flow rhythm or biology information, and are represented by the Tennant (Tennant, 1976), 7Q10 (Caissie et al., 1998) and range of variability (Richter et al., 1996) methods. Hydraulic approaches consider hydraulic parameters and contain simple biological information, but lack information on the effects of seasonal variation, such as wetted perimeter (Gippel and Stewardson, 1998) and R2Cross (Mosely, 1982). Habitatbased methods, extended from hydraulic method with the aim of providing adequate suitable places to aquatic organisms, consider biological information by quantifying the response of target species to hydro-environmental factors. 
The typical methods are the instream flow incremental method (IFIM) (Bovee, 1982) and the computer-aided simulation model for instream flow requirements (CASiMiR) (Jorde et al., 2000). Holistic approaches, such as the South African building block method (King and Low, 1998) and the Australian integrated assessment method (Arthington et al., 1992), take comprehensive ecological functions into account, but the required data are often too specific to be fulfilled, especially for areas lacking long-term data. In China, most rivers do not have adequate full-scale data to apply holistic methods; thus, habitat methods, which contain more ecological information than either hydrologic or hydraulic methods, are considered the most favourable approach. Since the development in the 1980s, habitat method, based on physical and chemical factors and their relations to target species, became an important tool for river management (Mouton et al., 2007). Besides IFIM and CASiMiR, Milner et al. (1998) and Minns et al. (1996) studied the response of fish habitat to population dynamics, including population number and age structure. Rosenfeld et al. (2011) investigated the effects of depth and velocity frequency distribution on habitat suitability of trouts. The habitat model for typical area, such as fluvial and lacustrine region, has also been developed (Wang and Lin, 2013). In addition, the algorithm for constructing suitability curve of habitat model development has been discussed as well (Boavida et al., 2014; Yi et al., 2014). However, previous habitat models have rarely considered habitat spatial distribution and specific life stage of riverine biota (Maeda, 2013; Marsili-Libelli et al., 2013; Mocq et al., 2013; Li et al., 2015; Zhao et al., 2015).

This study introduced landscape ecology concepts and developed an improved hydro-environmental-habitat model, which considered a habitat spatial index. The model was applied to a de-watered river reach, diverted for hydropower production, of the Yalong River, and estimated daily ecohydrographs for different habitat conservation levels during the spawning period of an indigenous fish species. Suitable ecological flow was determined for reservoir operations to adapt to and include ecological concerns.

\section{METHODS AND MATERIALS}

\section{Hydro-environmental model}

A two-dimensional hydro-environmental model was established to analyse changes in hydrological regimes because of reservoir regulation and to provide inputs to the fish habitat model. Water depth, flow velocity and water temperature were selected as the key parameters, which had been well investigated in previous studies ( $\mathrm{Li}$ et al., 2010; Li et al., 2011; Han et al., 2013). The governing equations of the hydrodynamic model were presented in $\mathrm{Li}$ et al. (2011). The convection diffusion equation was used to model water temperature, where the total solar radiation, the heat flux of water surface evaporation and the flux of heat conduction were taken into account (Li et al., 2011).

\section{Habitat suitability index}

Fuzzy logic was used in this study to assess fish habitat preference. The assessment model was a multi-input and single-output fuzzy system, comprised of three input variables (water depth, flow velocity and water temperature) and one output variable [habitat suitability index (HSI)] (Mouton et al., 2007, 2009; Muñoz-Mas et al., 2012; Mocq et al., 2013). The input variable values were provided by the hydro-environmental model results.

The initial membership degrees and inference rules were derived from laboratory experiments. In the experiments, the locations and residence times of fish were continuously recorded. Residence time was then converted into preference degree, and the locations were replaced by corresponding hydraulic parameters such as flow velocity and water depth (Yang et al., 2003; Han et al., 2010, 2011; Wang and Tan, 2010; Liang et al., 2011; Yuan et al., 2012; He et al., 2014). Because the laboratory experiments sometimes could not cover the range of parameters (e.g. flow velocity and water depth) measured in the field, we synthesized the data from the laboratory, field investigations and fish experts to optimize the membership degree and inference rules using a genetic algorithm (Figure 1). During the optimization process, the value of each breaking point of membership function and the fuzzy rules were coded in a binary string as an individual. The initial population was composed of 100 random individuals. The binary strings were converted to decimal values after each evaluation and were then used in the model. The corresponding model results were compared with the monitoring data to evaluate the strings. The strings with high performance were selected for duplication, crossover and mutation operations; thus, new strings were generated for next evolution. The processes were continued until a predefined iteration number was reached or the difference between model results and observation was smaller than a criterion.

In the fuzzy logic operation, the max-min approach (Moustakides and Verykios, 2008) was used for inference, and the centroid method (Francetic et al., 2005) was adopted for defuzzification, which transformed the fuzzy outputs into crisp values.

\section{Improved habitat assessment}

Previous studies focused mainly on habitat suitability, in particular the weighted usable area, but neglected the spatial distribution of the habitat quality. This study improved the habitat assessment model by introducing landscape ecology concepts such as habitat patchiness and habitat fragmentation. 


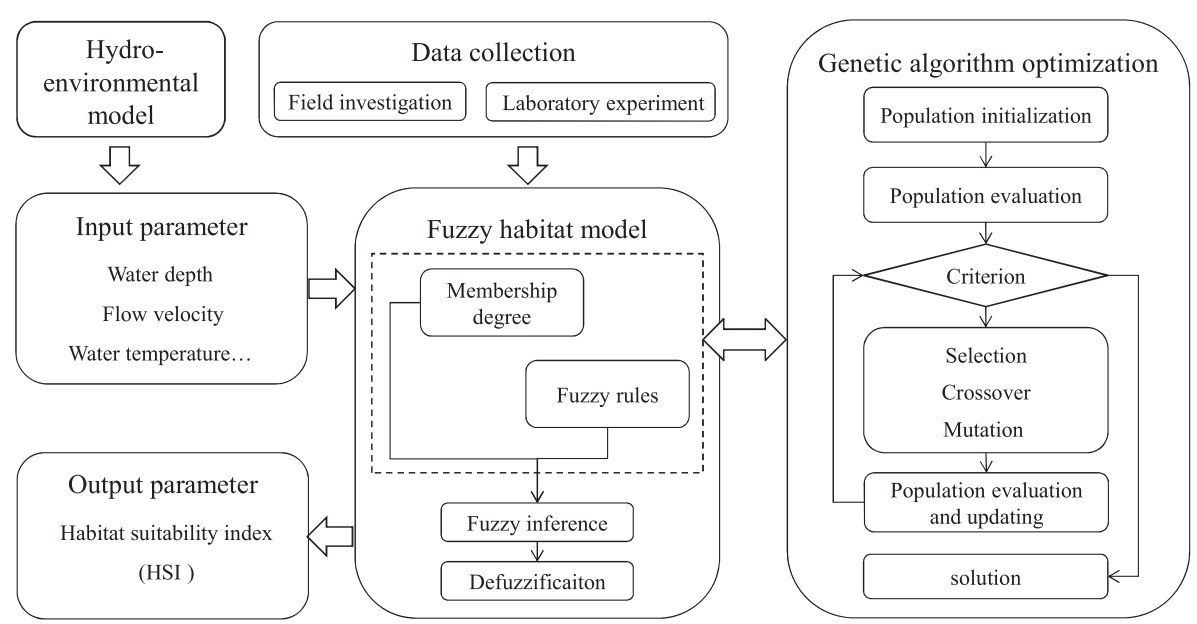

Figure 1. Schematic of the development and optimization of the fuzzy logic-based habitat model.

\section{Habitat patchiness}

The HSI describes how suitable a place is for a species to reside. Values vary from 0 to 1 , and typically 0 is poor habitat and 1 is excellent habitat. $H S I_{\text {cut }}$ is the threshold of $H S I$, which was set 0.5 in this study. Habitat patch is the place whose $H S I \geq H S I_{\text {cut }}$. Habitat patch number $n$ is the number of habitat patches. Habitat patch area $\mathrm{pa}\left(\mathrm{m}^{2}\right)$ is the area of a habitat patch.

\section{Improved hydraulic habitat suitability index}

The hydraulic habitat suitability index (HHS) was first proposed by the US Fish and Wildlife Service (Mouton et al., 2007) and is used to evaluate the general suitability of a studied area.

$$
H H S=\frac{1}{A} \sum_{i=1}^{m} a_{i} H S I_{i}
$$

where $a_{i}$ is the area of cell $i, \mathrm{~m}^{2} ; A$ is the total studied area, $\mathrm{m}^{2} ; H S I_{\mathrm{i}}$ is the habitat suitability index of cell $i ; m$ is the total number of cells and $m \geq n$. Under this definition, however, two different situations are possible for the same $H H S$ value: one is that all cells have a nearly average suitability, and the other is that some cells have high suitability, while others have low suitability. In reality, places with very low suitability are impractical for fish residence. To more precisely describe habitat conditions, an improved hydraulic habitat suitability index (IHHS) is proposed in Equation (2):

$$
I H H S=\frac{1}{A} \sum_{k=1}^{n} p a_{k} H S I_{k}
$$

where $p a_{k}$ is the area of habitat patch $k, \mathrm{~m}^{2}$ and $n$ is the habitat patch number.

\section{Habitat fragment index}

The averaged relative area of habitat patches, called the habitat fragment index (HFI) here, was used to describe habitat fragmentation. The smaller the value of the HFI, the more fragmented the habitats are.

$$
H F I=\frac{\sum_{k=1}^{n} p a_{k}}{n} / A
$$

where HFI is the habitat fragment index.

\section{Eco-hydrograph determination}

Eco-hydrographs were determined based on the relationship between discharge and fish habitat conditions, which was assessed by the improved habitat model. The variation range in water level is an extremely important factor during the fish spawning period (Zhou et al., 1980; Zeng, 1990; Hofreiter and Stewart, 2009; Appels et al., 2011; Forman et al., 2014; Jager, 2014; Sauterleute and Charmasson, 2014) and should be considered in eco-hydrograph estimations. In this paper, the variation range of the water level was taken into account in the design of ecological hydropeaking. The eco-hydrograph calculation procedure is illustrated in Figure 2, where $Q_{S}$ is the discharge corresponding to the peak value of IHHS, $Q_{R}^{t}$ is the river natural discharge at time $t, H_{R}^{t}$ is the corresponding water level of $Q_{R}^{t}$ and $p \%$ is the habitat conservation level, which is the ratio of conserved habitat area to the habitat area under natural flow condition. $Q_{P \%}^{t}$ is the discharge at time $t$ for habitat conservation level of $p \%, H_{P \%}^{t}$ is the corresponding water level of $Q_{P \%}^{t}, Q_{P \%, M}^{t}$ is the modified discharge at time $t$ when habitat conservation level is $p \%$, $H_{P \%, M}^{t}$ is the corresponding water level of $Q_{P \%, M}^{t}, Q_{P \%, E}^{t}$ is the ecological flow dedicatedly released from the reservoir at time $t$ and $I H H S_{\mathrm{P} \%}$ is the value of $I H H S$ when habitat conservation level is $p \%$.

When $Q_{R}^{t}$ was smaller than $Q_{S}$, discharge for the expected habitat conservation level was calculated according to the 


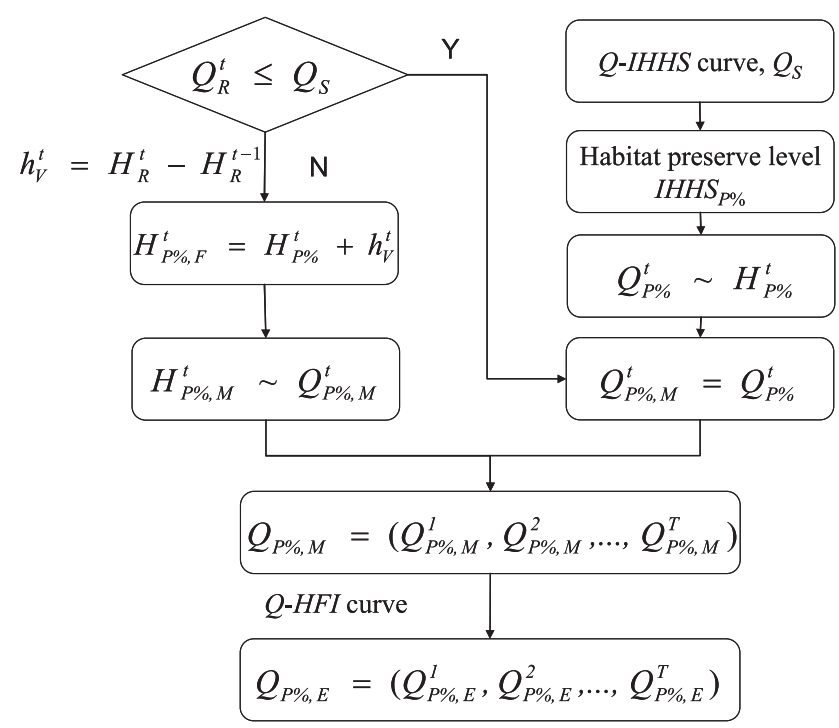

Figure 2. Diagram of eco-hydrograph calculation.

$I H H S$ value; otherwise, $h_{V}^{i}$ provided a similar water level variation to spawning fish through the $Q-H$ relationship.

\section{Case description}

The developed model was applied to the Yalong River in southwest China. Two cascaded reservoirs, Jinping-I and Jinping-II, were constructed in 2011 in the middle reach of the river. Figure 1 depicts the configuration of the cascaded reservoirs and the de-watered river reach. Jinping-I is a $305 \mathrm{~m}$ high concrete dam, and its power plant is situated at the dam toe. Jinping-II is located immediately downstream of Jinping-I and is much lower; however, a $288 \mathrm{~m}$ energy head has been provided by shortcutting a $120 \mathrm{~km}$ long loop of the natural river (Dahewan Reach) through four diversion tunnels (Figure 3). The diversion-type power plant of Jinping-II is located at the end of the diversion tunnels.

In the absence of remediation measures, the operation of the two cascaded reservoirs dramatically reduces the flow in the $120-\mathrm{km}$ long natural channel and even causes dry sections. This has seriously damaged the habitat of indigenous fish species. Schizothorax chongi, which is a dominant and commercial local fish, experiences considerable impact, particularly from March to June when they are spawning, because their spawning grounds are distributed in the de-watered river channels (Figure 3; Li et al., 2011). To protect the fish habitats, a certain amount of ecological flow must be released into the $120 \mathrm{~km}$ river channel through the spillway of Jinping-II.

\section{RESULTS}

The hydro-environmental model was calibrated by data in an even flow year (2001) and was then validated by the data in a high-flow year (2005). The relative errors of model were less than $6 \%$ for flow calculations and $10 \%$ for water quality calculations after calibration. More details on the calibration and validation of the hydroenvironmental model could be found in Li et al. (2011). The calibrated model could provide the basic inputs for the habitat model.

\section{Habitat assessment}

S. chongi prefers spawning in fast-flowing, shallow water within a temperature range of 10 to $18^{\circ} \mathrm{C}$. The indoor single-factor control experiments were performed at the Yangtze River Fish Conservation Centre and China Three Gorges University (Li et al., 2011, 2014; Han et al., 2013). The final membership functions are given in Figure 4, and the fuzzy rules, which were implemented through a set of if-and-then clauses, are shown in Table I.

According to field investigations conducted in May 2011, there were four major spawning sites in the river section (Figures 5A, B, C and D). The HSI values of these four zones in May were high (larger than 0.5), indicating that the model provided reliable assessment.

Through the habitat assessment model, the relationships between discharge and IHHS/HFI were established, as shown in Figure 6. Both IHHS and HFI initially increased with discharge and then decreased. The maximum IHHS and $H F I$ values appeared at discharges of 1700 and $400 \mathrm{~m}^{3} /$ $\mathrm{s}$ respectively. Because of the joint effects of the reduction in suitable habitat area and the increase in habitat patch numbers, $H F I$ exhibited a sharper decrease than that of IHHS (Figure 6).

\section{Eco-hydrograph estimation}

Taking the habitat condition corresponding to the daily averaged discharge in the $S$. chongi spawning period (March-June) during a normal flow year as a reference, daily average hydrographs were calculated for different habitat conservation levels ranging from 10 to $100 \%$ (the reference), as shown in Figure 7.

Average IHHS and $H F I$ values during the spawning period for different habitat conservation levels are shown in Figure 8 . The figure indicated that $I H H S$ had a jump around $50 \%$ habitat conservation level, but the curve before and after $50 \%$ has the same slope. Furthermore, HFI initially increased with habitat conservation level, but declined rapidly after the $50 \%$ conservation level. Thus, the ecohydrograph corresponding to the $50 \%$ habitat conservation level was recommended, with the related monthly average flows listed in Table II. For comparison, we also calculated ecological hydrographs by the Tennant (Tennant, 1976) and wetted perimeter (Lamb, 1989; Wang et al., 2009) methods, as shown in Figure 9. 

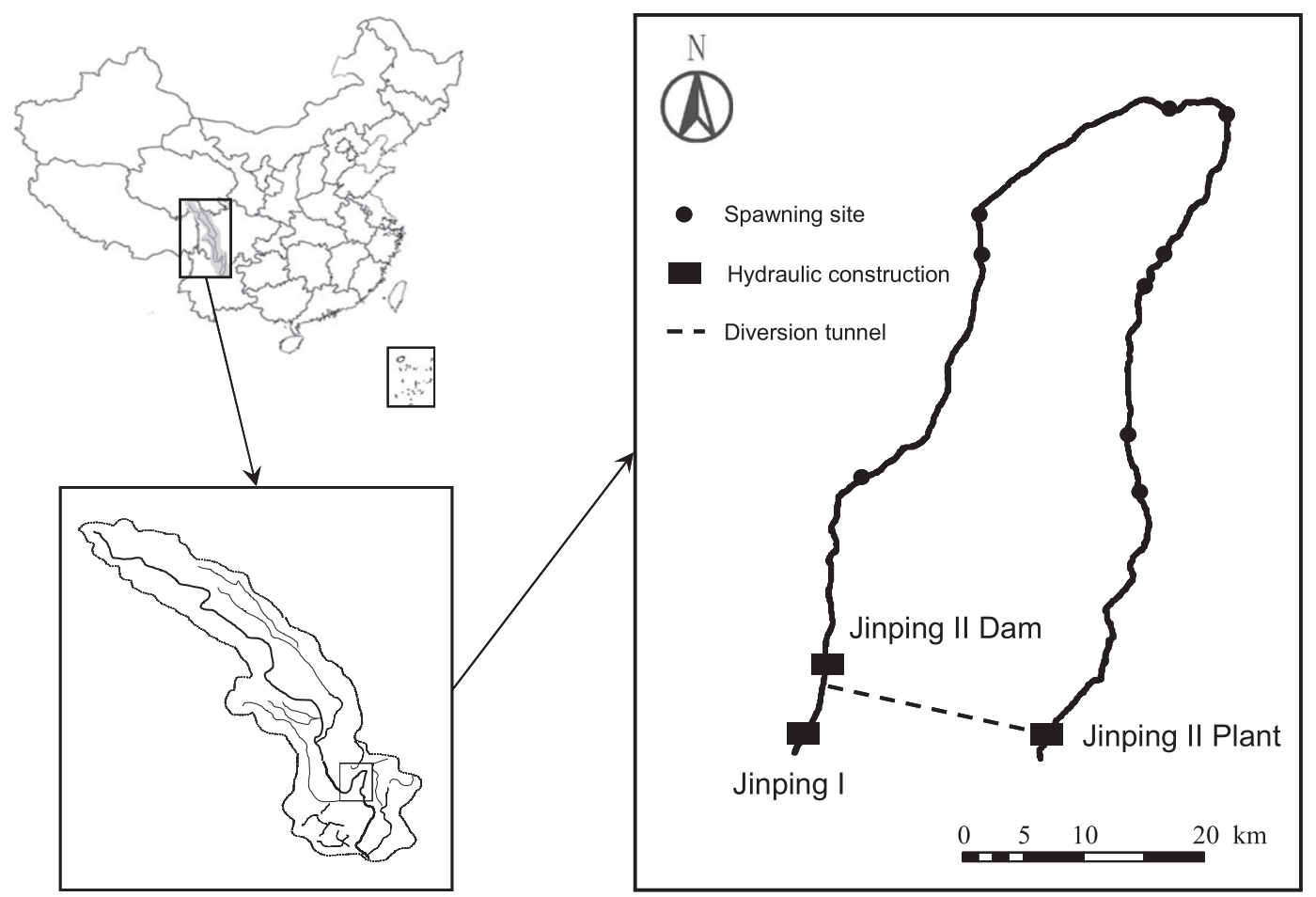

Figure 3. Sketch map of the de-watered river reach and the hydropower plants.
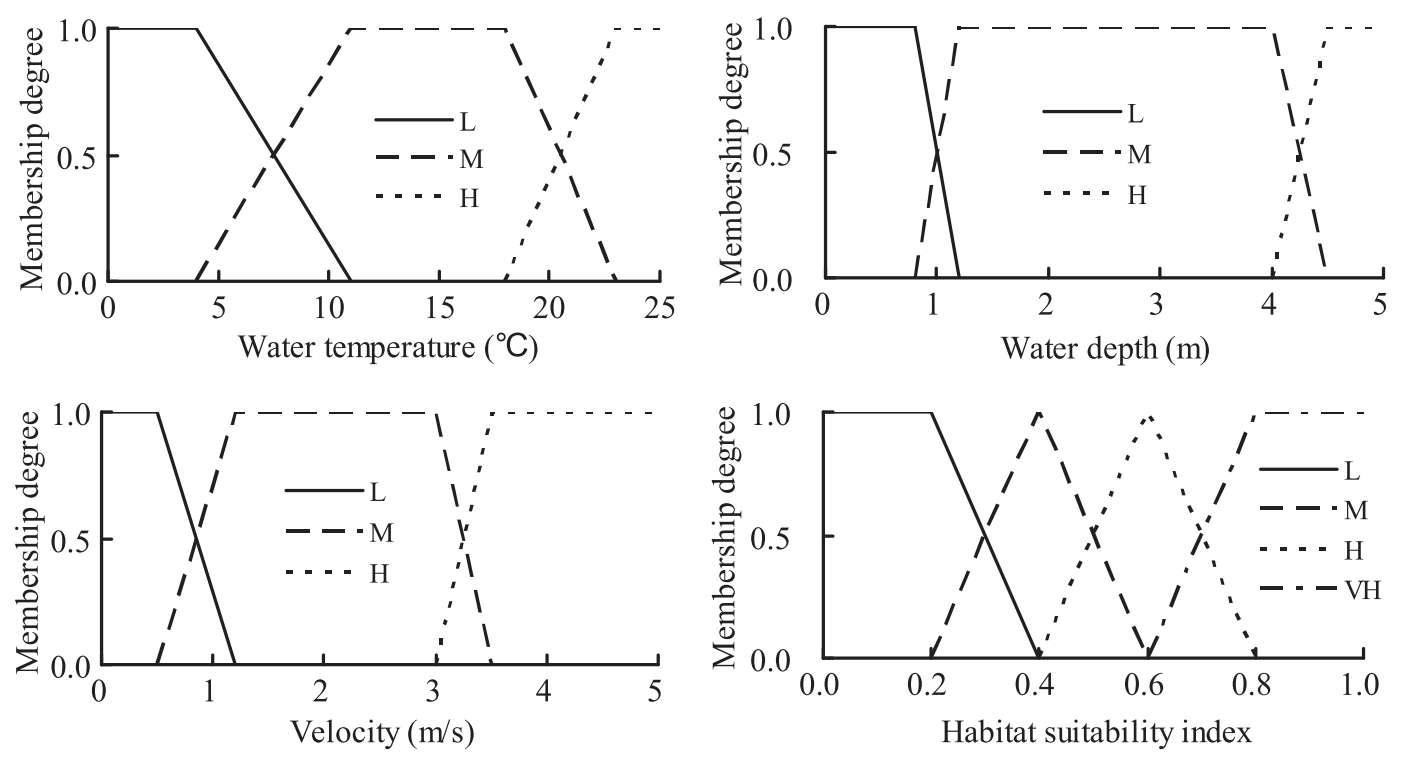

Figure 4. Membership degrees of the main hydro-environmental factors for the $S$. chongi spawning ground $(\mathrm{L}=$ low, $\mathrm{M}=$ medium, $\mathrm{H}=$ high, $\mathrm{VH}=\mathrm{very}$ high).

\section{DISCUSSIONS}

\section{Habitat suitability and habitat patchy analyses}

$H S I$, which varies from 0 to 1 , was the basis for habitat patchy (HFI) and IHHS analyses. HSI reflects the preference of target species to a joint condition of several environmental factors. Habitat patch is defined as a cluster of computing elements that are good, big and close enough to support breeding target species (Favilli et al., 2013). The cut-off value of $H S I\left(H S I_{\text {cut }}\right)$ was used to indicate 'good'. The cut-off value of $p a\left(p a_{\text {cut }}\right.$; Chen and $\mathrm{Wu}, 2013 ; \mathrm{Li}$ et al., 2015) was used to indicate 'big'. The HFI was used to indicate 'close'. Based on habitat patch, the IHHS was defined to describe the average condition of a river reach 
Table I. Fuzzy rule sets for $S$. chongi spawning ground assessment.

\begin{tabular}{lcccccccc}
\hline Parameters & WT & V & D & HSI & WT & V & D & HSI \\
Grades & L & L & H & L & M & M & M & VH \\
& L & L & M & M & M & M & H & H \\
& L & L & L & L & M & L & H & M \\
& L & M & M & M & M & L & M & H \\
& L & M & H & M & M & L & L & L \\
& L & H & H & L & M & H & H & M
\end{tabular}

WT = water temperature, $\mathrm{V}=$ velocity, $\mathrm{D}=$ water depth, $\mathrm{HSI}=$ habitat suitability index.

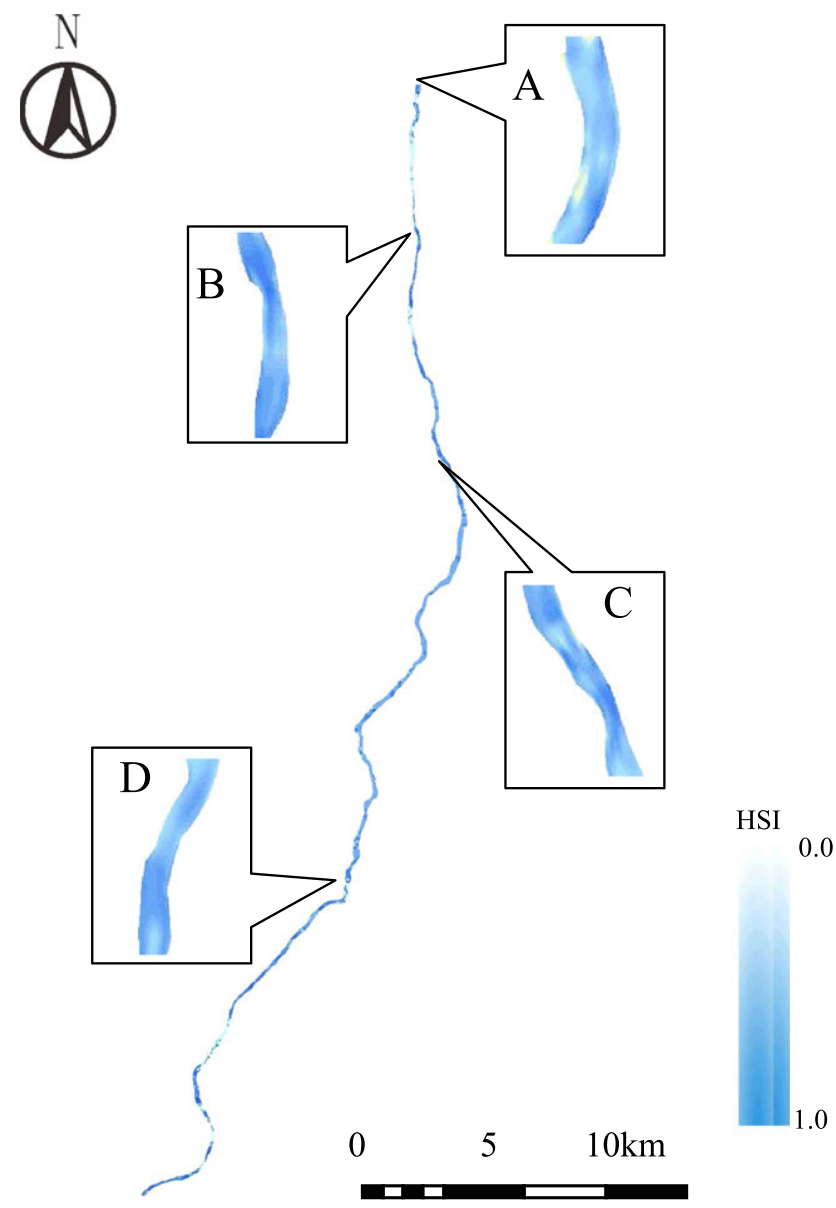

Figure 5. Results of the habitat model showing four major spawning sites (A: Qingna, B: Mianshawan, C: Jiangkou, D: Lizhuang, HSI: habitat suitability index).

for a species residence. For the threshold of HSI in this study, different values from 0 to 1 with an interval of 0.1 were tested. The difference consisted in the peak values of $I H H S$ and HFI, but the shape of the curves in Figure 6 remained. The IHHS increased rapidly and decreased gradually with the discharge, and the HFI increased sharply and decline rapidly with the discharge, and the corresponding discharge to the peak values was the same.
Therefore, the eco-hydrograph was not sensitively influenced by the cut-off value of $H S I$. In the research, the cutoff value of 0.5 was taken, because we thought at least being a threshold the unfavourite condition should not be higher than favourite condition. However, further investigations in this aspect were necessary in future study. It was also observed that $H F I$ varied steeper than IHHS along with discharge in Figure 6.The main reason was that $I H H S$ was only affected by suitability index; however, $H F I$ was affected by both suitability index and patch number.

\section{Eco-hydrograph comparison with traditional methods}

Typical hydrologic and hydraulic methods (represented by the Tennant and wetted perimeter methods respectively) were applied to calculate ecological flow requirements. The Tennant method is purely hydrological based, and there is no dedicated consideration of flow requirements for fish spawning. The discharge corresponding to the 'optimum' condition in the Tennant method was used to determine an ecological flow, denoted by Eco-Tennant in Figure 9. There was a significant difference between the EcoTennant discharge and natural discharge in the normal flow year, and it was difficult to meet the Eco-Tennant discharge in the dry season when power generation was in high demand.

The optimal ecological flow from the wetted perimeter method (Eco-WP) was $122 \mathrm{~m}^{3} / \mathrm{s}$, shown by the maximum curvature in Figure 9. The Eco-WP was easily satisfied, compared with the Eco-Tennant discharge. However, this fixed constant discharge ignored the fluctuation of natural flow, which is essential to species spawning.

The improved habitat method used in this paper not only considered habitat suitability but also habitat fragmentation. The crucial advantage of this method was the transformation of constant ecological flow into a dynamic eco-hydrograph.

\section{Implementation of eco-friendly reservoir operation}

In the practical implementation of eco-friendly reservoir operation, an eco-hydrograph can serve as a constraint of the optimization model and represent ecological interests (Chen et al., 2012, 2013).

Generally, discharge from turbines is part of the ecological flow downstream. However, the Jinping cascaded power stations are diversion type, and thus, ecological flow must be dedicatedly released from the reservoir, which inevitably leads to production loss. In previous studies ( $\mathrm{Li}$ et al., 2011; Chen et al., 2013), monthly eco-hydrographs were taken as a constraint for ecological operation. The recommended solution was to conserve $70 \%$ of $S$. chongi habitat at a cost of $5 \%$ power production loss. In this study, the daily eco-hydrographs were conducted specifically for the spawning period, which 

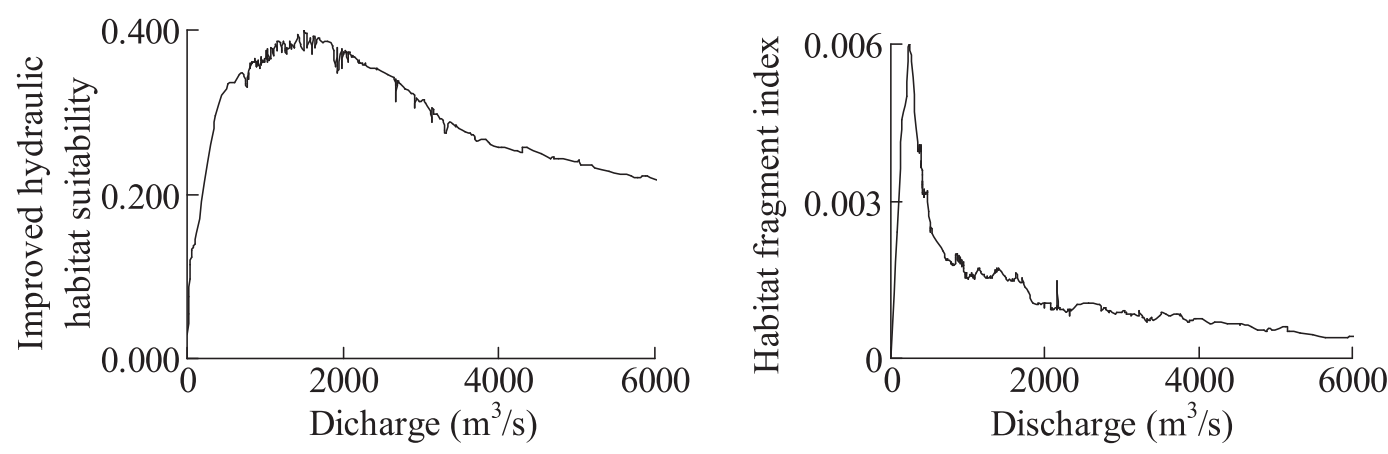

Figure 6. Relationship between discharge and improved hydraulic habitat suitability and habitat fragment index.

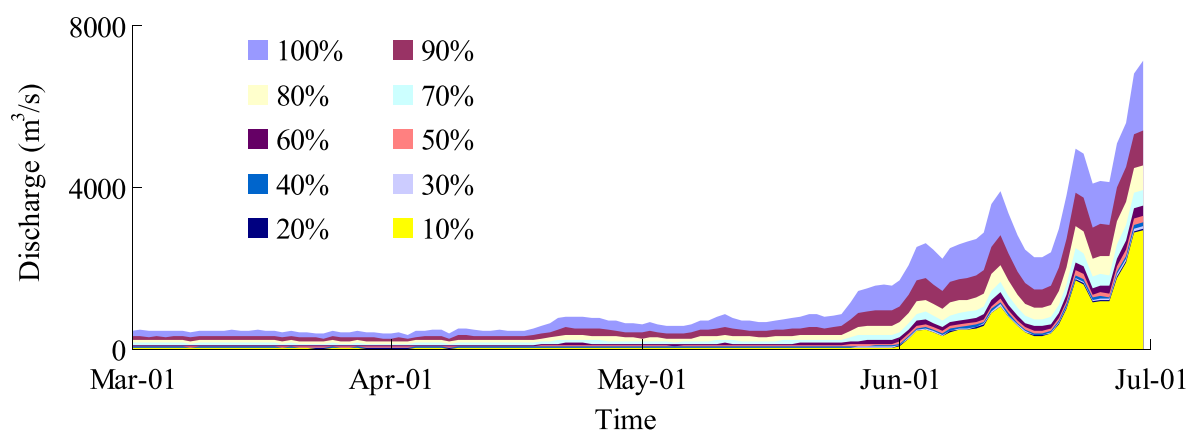

Figure 7. Eco-hydrographs for different conservation levels of $S$. chongi habitat.

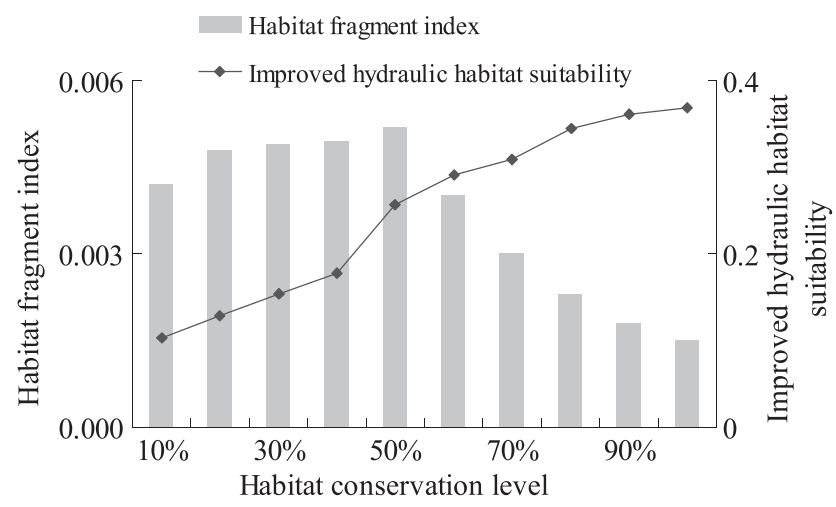

Figure 8. Average of improved hydraulic habitat suitability and habitat fragment index for different conservation levels of $S$. chongi habitat.

Table II. Monthly average flow pattern of 50 and $100 \%$ conservation levels.

\begin{tabular}{llcccc}
\hline Month & & March & April & May & June \\
\hline$Q\left(\mathrm{~m}^{3} / \mathrm{s}\right)$ & $50 \%$ (recommended) & 69.614 & 78.37 & 96.98 & 1095.99 \\
& $100 \%$ (reference) & 434.68 & 559.33 & 867.19 & 3455.07 \\
\hline
\end{tabular}

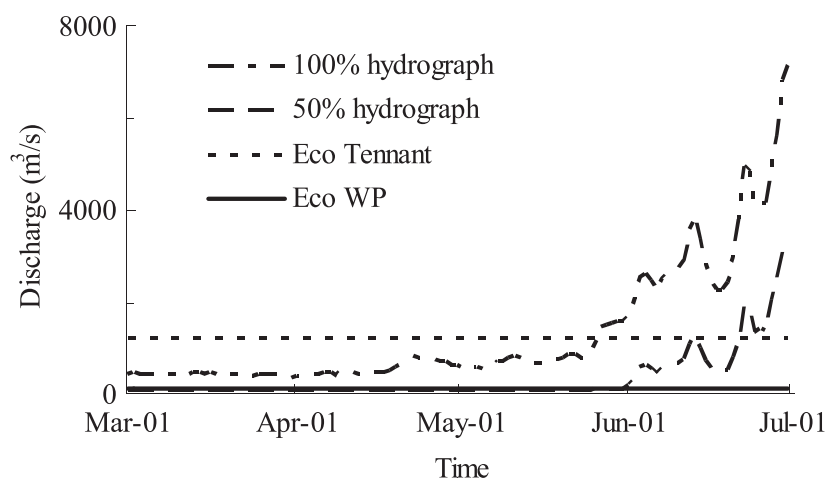

Figure 9. Comparison of eco-hydrographs among habitat model, Tennant method and wetted perimeter method.

showed that $50 \%$ habitat conservation was suitable for the species. The recommended daily eco-hydrographs indicated a more elaborate flow process, which could be of great assistance to water resource management.

\section{CONCLUSIONS}

Balancing water resources between social, economic and ecological demands is essential for river management. The accurate determination of eco-hydrographs not only 
strengthens aquatic ecosystem conservation but also improves water utilization efficiency. We developed a method for calculating daily eco-hydrographs based on a river habitat model, which considered both habitat quality properties and natural water level variations. The ecohydrograph corresponding to $50 \%$ conservation of the $S$. chongi spawning area was recommended. The developed method transformed traditional constant ecological flow into a dynamic eco-hydrograph, which was more ecologically meaningful and practically applicable.

\section{ACKNOWLEDGMENTS}

The research was supported by the National Natural Science Foundation of China (nos. 51109206, 51425902 and 51279196). The corresponding author was also supported by Guangxi Water Authority. We are grateful to Yalong River Hydropower Development Company, LTD (ylhdc@ylhdc.com.cn) and Chengdu Engineering Corporation Limited (chidi@chidi.com.cn) for providing hydrological data, meteorological data and river crosssectional data. The field survey data of fish habitats were obtained by the authors during 2008-2009. We also appreciate China Three Gorges University and Yangtze River Fish Conservation Centre for their assistance in fish behavioural experiments (huangyp@ctgu.edu.cn).

\section{REFERENCES}

Akter S, Grafton QR, Merritt WS. 2014. Integrated hydro-ecological and economic modeling of environmental flows: Macquarie Marshes, Australia. Agricultural Water Management 145: 98-109. DOI:10.1016/ j.agwat.2013.12.005.

Appels MW, Bogaart WP, Van der Zee EATMS. 2011. Influence of spatial variations of microtopography and infiltration on surface runoff and field scale hydrological connectivity. Advances in Water Resources 33(2): 303-313. DOI:10.1016/j.advwatres.2010.12.003.

Arthington AH, King JM, Pusey BJ. 1992. Development of an holistic approach for assessing environmental flow requirements of riverine ecosystem. In Proceedings of an International Seminar and Workshop on Water Allocation for the Environment, Pigram JJ, Hooper BP (eds). Centre for Water Policy Research, University of New England: Armidale, Australia; 69-79.

Boavida I, Dias V, Ferreira TM, Santos MJ. 2014. Univariate functions versus fuzzy logic: implications for fish habitat modeling. Ecological Engineering 71: 533-538. DOI:10.1016/j.ecoleng.2014.07.073.

Bovee KD. 1982. A guide to stream habitat analyses using the instream flow incremental methodology. In Instream Flow Information. US Fish and Wildlife Service: Washington; 67-73.

Caissie D, El-Jabi N, Bourgeois G. 1998. Instream flow evaluation by hydrologically-based and habitat preference (hydrobiological) techniques. Journal of Water science 11(3): 347-363. DOI:10.7202/ 705311 ar.

Chen Q, Chen D, Han R, Li R, Ma J. 2012. Optimizing the operation of the Qingshitan Reservoir in the Lijiang River for multiple human interests and quasi-natural flow maintenance. Journal of Environmental Sciences 24(11): 1923-1928. DOI:10.1016/S1001-0742(11)61029-2.

Chen Q, Duan C, Li R, Ma J, Blanckaert K. 2013. Adapting the operation of two cascaded reservoirs for ecological flow requirement of a dewatered river channel due to diversion-type hydropower stations.
Ecological Modelling 252: 266-272. DOI:10.1016/j.ecolmodel. 2012.03.008.

Chen Q, Wu S. 2013. Modelling and Remediation of Eco-Environmental Impacts Induced by Hydropower Projects. Scientific Press: Beijing; 55. Francetic M, Nagode M, Nastav B. 2005. Hierarchical clustering with concave datasets. Advances in Methodology and Statistics 2(2): 173-193.

Favilli F, Hoffmann C, Ravazzoli E, Streifeneder T. 2013. BioREGIO Carpathians, Advanced Tools and Methodologies Adopted GIS Model Design for Deriving Ecological Corridors. Pensoft Publishers: Sofia.

Forman LS, Wright KD, Bloszies C. 2014. Variations in water level for Lake Turkana in the past 8500 years near Mt. Porr, Kenya and the transition from the African Humid Period to Holocene aridity. Quaternary Science Reviews 97: 84-101. DOI:10.1016/j. quascirev.2014.05.005.

Gippel JC, Stewardson JM. 1998. Use of wetted perimeter in defining minimum environmental flows. Regulated Rivers: Research \& Management 14: 53-67. DOI:10.1002/(SICI)1099-1646(199801/02) 14:1<53::AID-RRR476>3.0.CO;2-Z.

Han J, Cao T, Liu G, Ma Z, Huang Y, Liu D, Chen Q. 2010. Effects of temperature and flow velocity on the respiratory metabolism of Schizothorax prenanti juveniles. Journal of Wuhan University (Natural Science Edition) 56(1): 81-86.

Han J, Huang Y, Yuan X, Liu G, Ma Z. 2011. Analysis on habitat suitability index of Schizothorax based OH fuzzy logic. Yangtze River 42(3): 65-68 78. DOI:10.3969/j.issn.1001-4179.2011.03.017.

Han R, Chen Q, Blanckaert K, Li W, Li R. 2013. Fish (Spinibarbus hollandi) dynamics in relation to changing hydrological conditions, physical modelling, individual-based numerical modelling, and case study. Ecohydrology 6(4): 586-597. DOI:10.1002/eco.1388.

Hanjra AM, Qureshi ME. 2010. Global water crisis and future food security in an era of climate change. Food Policy 35: 365-377. DOI:10.1016/j.foodpol. 2010.05.006

He Y, Wu X, Zhu Y, Li H, Li X, Yang D. 2014. Effect of rearing temperature on growth and thermal tolerance of Schizothorax (Racoma) kozlovi larvae and juveniles. Journal of Thermal Biology 16: 24-30. DOI:10.1016/j.jtherbio.2014.09.009.

Hess TM, Lennard AT, Daccache A. 2015. Comparing local and global water scarcity information in determining the water scarcity footprint of potato cultivation in Great Britain. Journal of Cleaner Production 87: 666-674. DOI: 10. 1016/j.jclepro.2014.10.075

Hofreiter M, Stewart J. 2009. Ecological change, range fluctuations and population dynamics during the Pleistocene. Current Biology 19(14): 584-594. DOI:10.1016/j.cub.2009.06.030.

Jackson S, Pollino C, Maclean K, Bark R, Moggridge B. 2015. Meeting Indigenous peoples' objectives in environmental flow assessments: case studies from an Australian multi-jurisdictional water sharing initiative. Journal of Hydrology 522: 141-151. DOI:10.1016/j. jhydrol.2014.12.047.

Jager IH. 2014. Thinking outside the channel, timing pulse flows to benefit salmon via indirect pathways. Ecological Modelling 273: 117-127. DOI:10.1016/j.ecolmodel.2013.11.007.

Jia J, Yuan Y, Zheng C, Ma Z. 2010. Dam construction in Chian: statistics, progresses and concerned issues. Water Power 36(1): 6-10. DOI:10.3969/j.issn.0559-9342.2010.01.002.

Jorde K, Schneider M, Zollner F. 2000. Analysis of instream habitat quality-preference functions and fuzzy models, In: Stochastic Hydraulics, Wang H (eds). Balkema: Rotterdam; 671-680.

King JM, Low D. 1998. Instream flow assessment for regulated rivers in South Africa using the building block methodology. Aquatic Ecosystem Health \& Management 1: 109-124. DOI:10.1080/ 14634989808656909.

Lamb BL. 1989. Quantifying instream flows, matching policy and technology. In Instream Flow Protection in the West. Island Press: Covelo, CA; 23-29.

Li R, Chen Q, Wu S, Cai D, Wang H. 2010. Application of fuzzy logic to model fish habitat in the downstream of Lijiang River under reservoir operations. Acta Ecologica Sinica 30(1): 128-137.

Li R, Chen Q, Chen D. 2011. Ecological hydrograph based on Schizothorax chongi habitat conservation in the dewatered river channel between Jinping cascaded dams. Science China-Technological Sciences 54: 54-63. DOI:10.1007/s11431-011-4614-7. 
Li R, Chen Q, Tonina D, Cai D. 2015a. Effects of upstream reservoir regulation on the hydrological regime and fish habitats of the Lijiang River, China. Ecological Engneering 76: 75-83. DOI:10.1016/j. ecoleng.2014.04.021.

Li W, Chen Q*, Cai D, Li R. 2015b. Determination of an appropriate ecological hydrograph for a rare fish species using an improved fish habitat suitability model introducing landscape ecology index. Ecological Modelling 311: 31-38

Liang J, Liu Y, Zhang X, Zhang X, Yue B, Song Z. 2011. An observation of the loss of genetic variability in prenant's schizothoracin, Schizothorax prenanti, inhabiting a plateau lake. Biochemical Systematics and Ecology 39(4-6): 361-370. DOI:10.1016/j.bse.2011.05.005.

Liu C, Zhao C, Xia J, Sun C, Wang R, Liu T. 2011. An instream ecological flow method for data-scarce regulated rivers. Journal of Hydrology 398: 17-25. DOI:10.1016/j.jhydrol.2010.11.026.

Maeda S. 2013. A simulation-optimization method for ecohydraulic design of fish habitat in a canal. Ecological Engineering 61: 182-189. DOI:10.1016/j.ecoleng.2013.09.026.

Marsili-Libelli S, Giusti E, Nocita A. 2013. A new instream flow assessment method based on fuzzy habitat suitability and large scale river modeling. Environmental Modelling \& Software 41: 27-38. DOI:10.1016/j.envsoft.2012.10.005.

Matthews HJ, Forslund A, McClain EM, Tharme ER. 2014. More than the fish: environmental flows for good policy and governance, poverty alleviation and climate adaptation. Aquatic Procedia 2: 16-23. DOI:10.1016/j.aqpro.2014.07.004.

Milner NJ, Wyatt RI, Broad K. 1998. HABSCORE: Applications and future developments of related habitat models. Aquatic Conservation: Marine and Freshwater Ecosystem 8: 633-644. DOI:10.1002/(SICI) 1099-0755(199807/08) 8: 4 633:AID-AQC275 3.0. CO;2-7.

Minns CK, Randall RG, Moore JE, Cairns VW. 1996. A model simulating the impact of habitat supply limits on northern pike, Essox lucius, in Hamilton Harbour, Lake Ontario. Canadian Journal of Fisheries and Aquatic Sciences 53: 20-34. DOI:10.1139/f95-258.

Mocq J, St-Hilaire A, Cunjak RA. 2013. Assessment of Atlantic salmon (Salmo salar) habitat quality and its uncertainty using a multiple-expert fuzzy model applied to the Romaine River (Canada). Ecological Modelling 265: 14-25. DOI:10.1016/j.ecolmodel.2013.05.020.

Mosely MP. 1982. Analysis of the effect of changing discharge on channel morphology and instream uses in a Braided River, Ohau River, New Zealand. Water Resources Research 18: 800-812. DOI:10.1029/ WR018i004p00800.

Moustakides VG, Verykios SV. 2008. A Max-Min approach for hiding frequent itemsets. Data \& Knowledge Engineering 65(1): 75-89. DOI:10.1016/j.datak.2007.06.012.

Mouton AM, De Baets B, Goethals PLM. 2009. Knowledge-based versus data-driven fuzzy habitat suitability models for river management. Environmental Modelling \& Software 24(8): 982-993. DOI: 10.1016/j. envsoft. 2009.02.005.

Mouton MA, Schneider M, Depestele J, Goethals LMP, DePauw N. 2007. Fish habitat modelling as a tool for river management. Ecological Engineering 3(29): 305-315. DOI:10.1016/j.ecoleng.2006.11.002.

Muñoz-Mas R, Martínez-Capel F, Schneider M, Mouton MA. 2012. Assessment of brown trout habitat suitability in the Jucar River Basin (SPAIN): comparison of data-driven approaches with fuzzy-logic models and univariate suitability curves. Science of the Total Environment 440: 123-131. DOI:10.1016/j.scitotenv.2012.07.074.

Richter BD, Baumgartner JV, Powell J, Braun PD. 1996. A method for assessing hydrologic alteration within ecosystems. Conservation Biology 10 (4): 1163-1174. DOI:10.1046/j.1523-1739.1996.10041163.x.
Rosenfeld SJ, Campbell K, Leung SE, Bernhardt J, Post J. 2011. Habitat effects on depth and velocity frequency distributions: implications for modeling hydraulic variation and fish habitat suitability in streams. Geomorphology 130(3-4): 127-135. DOI:10.1016/j.geomorph. 2011.03.007.

Sauterleute FJ, Charmasson J. 2014. A computational tool for the characterisation of rapid fluctuations in flow and stage in rivers caused by hydropeaking. Environmental Modelling \& Software 55: 266-278. DOI:10.1016/j.envsoft.2014.02.004.

Tennant DL. 1976. Instream flow regimens for fish, wildlife, recreation and related environmental resources. Fisheries 1(4): 6-10. DOI:10.1577/1548-8446(1976) 001<0006:IFRFFW > 2.0.CO;2.

Tharme RE. 2003. A global perspective on environmental flow assessment, emerging trends in the development and application of environmental flow methods for rivers. River Research and Applications 19: 397-441. DOI: $10.1002 /$ rra.736

UNESCO. 2012. Increasing demand and climate change threatening world water resources says new UN World Water Development Report. The World Water Forum in Marseille (France), http,//preventionweb.net/go/ 25612.

Jiang Y. 2009. China's water scarcity. Journal of Environmental Management 90: 3185-3196. DOI:10.1016/j.jenvman.2009.04.016.

Jowett IG. 1997. Instream flow methods, a comparison of approaches. Regulated Rivers: Research \& Management 13: 115-127. DOI:10.1002/(SICI)1099-1646(199703)13:2<115::AID-RRR440>3.0. $\mathrm{CO} ; 2-6$.

Wang F, Lin B. 2013. Modelling habitat suitability for fish in the fluvial and lacustrine regions of a new Eco-City. Ecological Modelling 267: 115-126. DOI:10.1016/j.ecolmodel.2013.07.024.

Wang Q, Li J, Li K, Li R. 2009. Modification of wetted perimeter method for determining the ecological flow requirement. Journal of Hydraulic Engineering 40(5): 550-555 563. DOI:10.3321/j.issn:05599350.2009.05.006.

Wang Y, Tan Y. 2010. Preliminary analysis of hydraulic characteristics on natural ecological environment of Schizothorax. Sichuan Water Conservancy 6: 55-59.

Yang Y, Li S, Zhou X, Duan Y. 2003. The biology and cultivation of Schizothoracinae. Reservoir Fisheries 23(4): 22-23.

Yi Y, Tang C, Yang Z, Chen X. 2014. Influence of Manwan Reservoir on fish habitat in the middle reach of the Lancang River. Ecological Engineering 69: 106-117. DOI:10.1016/j.ecoleng.2014.03.026.

Yuan X, Tu Z, Han J, Wang X, Shi X, Liu G, Huang Y. 2012. Effects of flow rate on swimming behavior and energy consumption of Schizothorax chongi. Acta Hydrobiologica Sinica 2: 270-275. DOI:10.3969/j.issn.1003-1278.2003.04.010.

Zeng X. 1990. Study on the promotion of natural reproduction of domestic fish by regulating water rising. Chinese Journal of Ecology 9 (4): 20-23.

Zhao CS, Yang ST, Liu CM, Dou TW, Yang ZL, Yang ZY, Liu XL, Xiang H, Nie SY, Zhang JL, Mitrovic SM, Yu Q, Lim RP. 2015. Linking hydrologic, physical and chemical habitat environments for the potential assessment of fish community rehabilitation in a developing city. Journal of Hydrology 523: 384-397. DOI:10.1016/j. jhydrol.2015.01.067.

Zhao Z, Liu J, Sacenije HG. 2013. A simple approach to assess water scarcity integrating water quantity and quality. Ecological Indicators 34: 441-449. DOI:10.1016/j.ecolind.2013.06.012.

Zhou C, Liang T, Huang H. 1980. Ecological features of the spawning of certain fishes in the Hanjiang River after the construction of dams. Acta Hydrobiologica Sinica 7(2): 175-188. 